\title{
Evaluation of Antimicrobial Activity of Selected Green Extracts
}

\author{
Nabaneeta Gogoi*, Parishmita Neog and Dibyashree Saikia
}

Department of Textiles and Apparel Designing, All India Coordinated Research Project on

Home Science, College of Community Science, Assam Agricultural University, Jorhat, India

*Corresponding author

\section{A B S T R A C T}

Keywords

Green extract, Antimicrobial, Phenolic content, Agar-Well diffusion

Article Info

\section{Accepted:}

12 April 2021 Available Online: 10 May 2021
Antimicrobial activity of five (5) different green(plant) extracts from Kharpat (Cassia alata Linn), Neem (Azadirachta indica), Tulsi (Ocimum basilicum), Dhatura (Datura fastuosa) and $\mathrm{Gu}$ phool (Lantana camera L.) were evaluated against two human pathogens i.e. Staphylococcus aureus and Proteus vulgaris through the agar-well diffusion method. The purpose of the study was to calculate the Total Phenolic Content (TPC), evaluation of the antimicrobial activity to provide information for further use of the plant extracts in antimicrobial textile finishing which is one of the important aspects in terms of textile finishing in present scenario.

\section{Introduction}

Antimicrobial finishing of textile fabrics have a great interest in scientific researches during recent years. People are very much conscious about hygiene and cleanliness in every aspect and there is necessity and expectation for a wide range of textile products finished with antimicrobial treatments. The textile materials and clothing items not only plays the role as carriers of microorganism but also as a good media for microbial growth. The growth of microbes on textiles during use and storage remarkably affects the wearer as well as the textile itself. The microbial attack on textile material results in detrimental effects on the consumer and the fabric itself in terms of odour formation, strength reduction, risk of contamination along with loss of quality of the textile material. Therefore, the antimicrobial treatment for textile material is became necessary to avoid cross infection by pathogenic micro-organism, to control the infestation by microbes, arrest metabolism in microbes in order and to safeguard the textile products from staining, discolour and quality deterioration. This finish prevents the growth of microbes and the antimicrobial finished products have been proved environment friendly, health protecting and preventing diseases. Odour as well as skin problems caused by microbial growth can be reduced by 
emphasizing the hygiene nature of the treated product. This antimicrobial finishes inhibits the growth of microorganisms, such as bacteria, fungi, viruses algae, mold and mildew. Micro-organism growth is another important factor that has resulted in development of antimicrobial textile finish.

Plants are rich in a wide range of secondary metabolites, such as phenols, alkaloids, flavonoids, glycosides, tannins and terpenoids which have been found to have antimicrobial properties. Due to the potential toxicological effects of synthetic antioxidants, natural antioxidants such as phenols and flavonoid compounds from plant origin are gaining popularity these days.

An anti-oxidant is a substance that inhibit or delays oxidative damage to the cells of the organisms by scavenging the free radicals such as peroxide or hydroperoxide and thus reducing the risk of degenerative diseases. The aim of present study was to calculate the Total Phenolic Content (TPC) and evaluation of its antimicrobial activity.

\section{Materials and Methods}

\section{Plant sources}

For evaluation of antimicrobial activity, 5 different plants were selected based on their various properties like anti-microbial, antiitching, anti-allergic, anti-septic UV protection, mosquito repellency etc. Leaves of Tulsi (Ocimum basilicum), Neem (Azadirachta indica), Gu phool (Lantana camera L.), Dhatura, (Datura fastuosa) and Kharpat (Cassia alata Linn) were collected from the local area of Assam Agricultural University, Jorhat. The leaves were washed, shade dried and ground into powder in laboratory mixer/blender. The fine powder was obtained by passing the substrate through sieve to separate the unwanted residues.

\section{Preparation of extract}

A well known quantity of leaf powder was mixed in $70 \%$ ethanol and distilled water and incubated for 24 hours at room temperature. The extract was centrifuged at room temperature 10,000 rpm and supernatant was filtered using whatman filter paper. The extracts were stored at $8^{0} \mathrm{C}$ for further experiments.

\section{Total Phenolic content (TPC)}

TPC was determined by Folin-Ciocalteu colorimetric method using Gallic acid as standard. All the solvent extracts were mixed with $2 \mathrm{ml}$ of $10 \% \mathrm{Na}_{2} \mathrm{CO}_{3}$ solution. $100 \mu \mathrm{l}$ of Folin-Ciocalteu reagent was added to the mixture after incubated for $3 \mathrm{~min}$ at room temperature. The resulting solution was incubated at room temperature for $90 \mathrm{~min}$ under dark. The absorbance was measured at $750 \mathrm{~nm}$ using the UV-Vis Spectrophotometer. The TPC was expressed as Gallic acid equivalent (GAE) in miligrams per gram of fresh leaf.

\section{Bioassay of plant extracts}

To assess the antimicrobial activity of the plant extracts, Bioassay was carried out by Agar-well diffusion method. The bacteria species viz., Staphylococcus auresus (ATCC 11632) and Proteus vulgaris (MTCC 426) were used for the study.

The plant extracts were coded as Kharpaat-1, Neem-2, Tulsi-3, Dhatura-4 and Guphool-5 for assessment of antimicrobial activity using Agar-well diffusion method. the study.

For the assessment, nutrient media and nutrient broth was prepared separately in distilled water and autoclaved for $15 \mathrm{~min}$ at $120^{\circ} \mathrm{C}$ at a pressure of $15 \mathrm{lb}$. A loopful of bacterial cultures (S.auresus and P.vulgaris) 
was mixed separately in the nutrient broth and kept for 24 hours under shaking condition. The bacterial inoculum was uniformly spread on sterile Petri plates and allowed to solidify. After solidification, six wells were created using a cork borer (10mm diameter) putting one at the centre for the control sample. The ethanol extracts of selected plant sources were added to each of the respective five wells. The Petri plates were incubated for 24 hours for observation of bacterial growth. Zone of inhibition of the bacterial growth was measured in $\mathrm{nm}$. Concentration of the extracts was taken constant.

\section{Results and Discussion}

\section{Yield of plant extracts}

Yield of plant extracts were measured in $\mathrm{ml}$. From the Table 2 it was found that maximum yield of extract showed in ethanol extract compared to aqueous extract in all five sources of green extracts. Maximum yield of extract were found in Ocimum basilicum and Lantana camera $L$ in case of ethanol extract whereas in aqueous extract highest yield of extract noticed in Ocimum basilicum extract (46ml).

\section{Total Phelonic Content (TPC)}

The Folin-Ciocalteu reagent is reduced to blue oxides of tungstene and molybdene during phenol oxidation. This reaction occurs due to the presence of sodium carbonate provided under alkaline condition. The presence of quantity of phenolic compounds in the green extracts can be identified by the intensity of blue colour, which can be measured using spectrophotometer. From the table 3, it was revealed that TPC concentration of all the extracts was found to be high in ethanol extract. TPC concentration of Cassia alata
Linn was found to be high in ethanol extracts (51.98) followed by Azadirachta indica (49.93), Ocimum basilicum (34.60), Datura fastuosa (30.91) and Lantana camera $L$. (23.39) respectively. On the other hand, in aqueous extract, Cassia alata Linn (50.97) was found to be high in TPC concentration followed by Azadirachta indica (32.39), Datura fastuosa (23.33), Ocimum basilicum (20.03) and Lantana camera L. (14.10) respectively.

\section{Antimicrobial Effect of plant extracts}

All five green extracts (Ethanol) showed different degrees of inhibition zones against both the test organism. The result of antimicrobial activity is shown in the Plate 1 and 2 and summarized in Table 4.

From table 4, it was observed that, among all the plant extracts, the Cassia alata Linn and Ocimum basilicum (11) leaf extracts showed maximum zone of inhibition against Staphylococcus aureus followed by Azadirachta indica (10) and Lantana camera L. (10). In case of Proteus vulgaris, no such antimicrobial activity has observed in all the extracts.

The results obtained from the present study provide a basis idea about the presence of antimicrobial activity of selected green extracts, i.e. Kharpat (Cassia alata Linn), Neem (Azadirachta indica), Tulsi (Ocimum basilicum), Dhatura (Datura fastuosa) and $\mathrm{Gu}$ phool (Lantana camera L.). From the study, was observed that there was antibacterial activity against Staphylococcus aureus, on Kharpat (Cassia alata Linn), Neem (Azadirachta indica), Tulsi (Ocimum basilicum), and Gu phool (Lantana camera L.) with a range of (10-11) $\mathrm{mm}$ Zone of inhibition. 
Table.1 Sample coding

\begin{tabular}{|c|c|}
\hline Name of the plant extracts & Sample Code \\
\hline Kharpat (Cassia alata Linn) & 1 \\
\hline Neem (Azadirachta indica) & 2 \\
\hline Tulsi (Ocimum basilicum) & 3 \\
\hline Dhatura (Datura fastuosa) & 4 \\
\hline Gu phool (Lantana camera L.) & 5 \\
\hline
\end{tabular}

Table.2 Yield of plant extracts

\begin{tabular}{|c|c|c|c|}
\hline \multirow{2}{*}{$\begin{array}{c}\text { Sample } \\
\text { code }\end{array}$} & Plant Source & \multicolumn{2}{|c|}{ Yield of extracts (ml/50ml) } \\
\cline { 3 - 4 } & & Ethanol & Aqueous \\
\hline $\mathbf{1}$ & Kharpat (Cassia alata Linn) & $47 \mathrm{ml}$ & $42 \mathrm{ml}$ \\
\hline $\mathbf{2}$ & Neem (Azadirachta indica) & $46 \mathrm{ml}$ & $43 \mathrm{ml}$ \\
\hline $\mathbf{3}$ & Tulsi (Ocimum basilicum) & $48 \mathrm{ml}$ & $46 \mathrm{ml}$ \\
\hline $\mathbf{4}$ & Dhatura (Datura fastuosa) & $45 \mathrm{ml}$ & $42 \mathrm{ml}$ \\
\hline $\mathbf{5}$ & Gu phool (Lantana camera L) & $48 \mathrm{ml}$ & $45 \mathrm{ml}$ \\
\hline
\end{tabular}

Table.3 Phenolic contents of plant extracts

\begin{tabular}{|c|c|c|}
\hline \multirow{2}{*}{ Name of the plant extracts } & \multicolumn{2}{|c|}{$\begin{array}{c}\text { Total Phenolic Content } \\
\text { (GAE* mg/g) }\end{array}$} \\
\cline { 2 - 3 } & Ethanol & Aqueous \\
\hline Kharpat (Cassia alata Linn) & 51.98 & $\mathbf{5 0 . 9 7}$ \\
\hline Neem (Azadirachta indica) & 49.93 & $\mathbf{3 2 . 3 9}$ \\
\hline Tulsi (Ocimum basilicum) & 34.60 & $\mathbf{2 0 . 0 3}$ \\
\hline Dhatura, (Datura fastuosa) & 30.91 & $\mathbf{2 3 . 3 3}$ \\
\hline Gu phool (Lantana camera L.) & $\mathbf{2 3 . 3 9}$ & $\mathbf{1 4 . 1 0}$ \\
\hline
\end{tabular}

Table.4 Antimicrobial activity of plant extracts by Agar Well diffusion method

\begin{tabular}{|c|c|c|c|c|}
\hline \multirow[t]{2}{*}{ Sl.No. } & \multirow[t]{2}{*}{ Green extracts } & \multirow{2}{*}{$\begin{array}{c}\text { Concentration } \\
\%\end{array}$} & \multicolumn{2}{|c|}{ Zone of inhibition(mm) } \\
\hline & & & $\begin{array}{c}\text { Staphylococcus } \\
\text { aureus }\end{array}$ & $\begin{array}{l}\text { Proteus } \\
\text { vulgaris }\end{array}$ \\
\hline 1 & Kharpat (Cassia alata Linn) & 10 & 11 & NI \\
\hline 2 & Neem (Azadirachta indica) & 10 & 10 & NI \\
\hline 3 & Tulsi (Ocimum basilicum) & 10 & 11 & NI \\
\hline 4 & Dhatura, (Datura fastuosa) & 10 & $\mathrm{NI}$ & NI \\
\hline 5 & Gu phool (Lantana camera L.) & 10 & 10 & NI \\
\hline
\end{tabular}




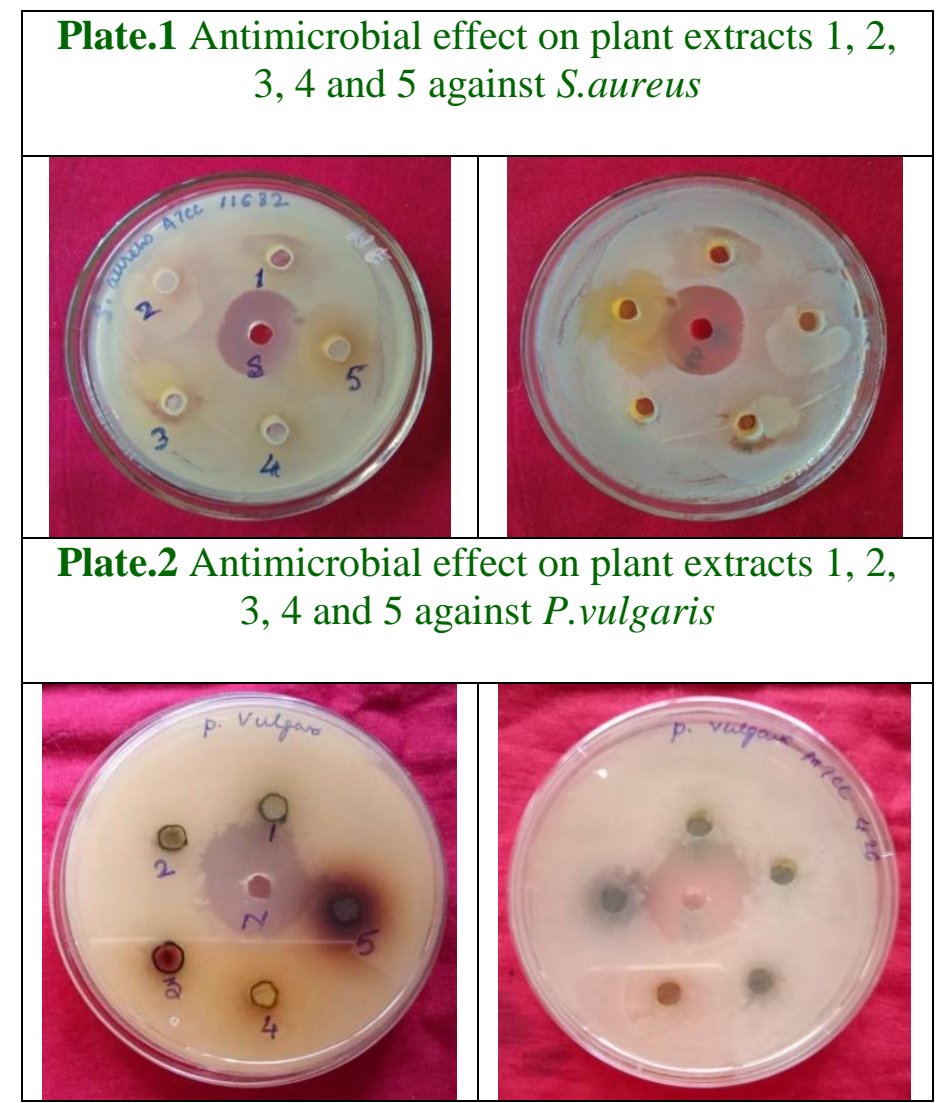

On the other hand, it was observed that, there was no antibacterial activity on all the selected green extracts against Proteus vulgaris. Further research is encouraged on the extraction process, assessment of antimicrobial activity imparting different extraction media and concentration respectively.

\section{References}

Gomathinayagam S. et al., (2014), Studies of Antimicrobial Properties of Different Leaf Extract of Tulsi (Ocimum tenuiflorum) against Human Pathogens, American International Journal of Contemporary Research, Vol. 4, No. 8.

Archana, S. et al., (2011) Comparative analysis of antimicrobial activity of leaf extracts from fresh green tea, commercial green tea and black tea on pathogens, Journal of Applied
Pharmaceutical Science Vol:01 (08), pp: 149-152.

Shinkafi, S. A. et al., (2013), Antibacterial Activity of Allium Cepa (Onion) On Some Pathogenic Bacteria Associated With Ocular Infections, Scholars Journal of Applied Medical Sciences, ISSN 2320-6691, Vol:1(3), pp:147151.

Vastard, J. V. et al., (2018), Eco friendly Antimicrobial Finishing of Cottton Fabric using Plant Extracts, International Journal of Current Microbiology and Applied Sciences, ISSN:2319-7706, Vol:7(2), pp: 284292.

Vastard, J. V. et al., (2016), Characterization of phelonic compounds in Eucalyptus globulus and Cymbopogan citratus leaf extracts, The Bioscan, Vol:11(4), pp:2153-2156.

Vastard, J. V. et al., (2015), Identification of bio-active components in leaf extracts 
of Aloe vera, Ocimum tenuiflorum (Tulsi) and Tinospora cordifolia (Amrutballi), journal of Medicinal Plants Research, Vol:9(28), pp:764770.
Phuyal, N. et al., (2020), Total Phenolic, Flavonoid Contents, and Antioxidant Activities of Fruit, Seed, and Bark Extracts of Zanthoxylum armatum DC, The Scientific World Journal.

\section{How to cite this article:}

Nabaneeta Gogoi, Parishmita Neog and Dibyashree Saikia. 2021. Evaluation of Antimicrobial Activity of Selected Green Extracts. Int.J.Curr.Microbiol.App.Sci. 10(05): 288-293. doi: https://doi.org/10.20546/ijcmas.2021.1005.036 